\title{
Testing Various Econometric Models Of Internal Migration In Italy
}

\author{
Dominick Salvatore*
}

\section{Introduction}

In recent years there have been a number of studies on the socioeconomic determinants of human migration in this journal and elsewhere. ${ }^{1}$ Most of these migration studies utilized census data because of lack of time series data. One exception was the excellent article by Walsh [19] studying Irish migration to Britain. The present study follows Walsh in testing the same econometric models but for internal (South-North) migration in Italy. The present study utilizes somewhat more reliable and disaggregated data than used by Walsh, tests some additional relevant variables, and obtains results which are statistically more significant and which also conform better with theoretical dictates.

The Italian South includes about one-third of the population and labor force of Italy and has an average per capita income of about two-thirds the national average. Over the seventeen-year period of the analysis (1958-1974 inclusive), one million workers (about 17\% of the labor force of the South) emigrated from the South to the North. Of this, $65 \%$ went to the Northwest (the four richest and most industrialized of the twelve regions of the North), $23 \%$ to the four regions of the Center, and $12 \%$ to the Northeast (which has also been an area of net migration to the rest of the North).

Migration data in Italy is generated by a system of population registers, whereby people changing address are required by law to report the change of address. Registration is also a prerequisite for all sorts of social security benefits. Migration data, broken down into workers and non-workers, is collected and published annually (since 1958) by the Central Statistical Institute in Rome [8] [10].

\section{The Models}

Human migration from a given region has been postulated as a response to better socio-economic conditions in other areas. These include greater employment opportunities and higher earnings. Greater employment opportunities are measured by lower unemployment rates and higher em-

\footnotetext{
*Associate Professor of Economics, Fordham University. This study was made possible by a Fullbright Research Award to Italy for the last academic year and is part of a larger study on internal migration in Italy near completion. The author is grateful to Professor C. Pace, A. Golini, G. Schacter, G. Colombo and A. Falciglia for helpful comments and to Dr. Glenn De Souza and $\mathrm{E}$. Malfatti for helping with the data, but he alone is responsible for any remaining shortcomings.
} 
ployment growth rates. ${ }^{2}$ Earnings are measured by average real industrial wages and alternatively by the average real income per employed worker. $^{3}$

Thus, the variables used in this study are:

$\mathrm{M}_{\mathrm{SN}_{\mathrm{t}}}=$ net number of workers emigrating from the South to the North during year $t$, per 1,000 of the labor force of the South

$U_{\mathrm{t}}=\left(\mathrm{U}_{\mathrm{S}}-\mathrm{U}_{\mathrm{N}}\right)_{\mathrm{t}}$ or $\left(\frac{\mathrm{U}_{\mathrm{S}}}{\mathrm{U}_{\mathrm{N}}}\right)_{\mathrm{t}}=$ difference or ratio in the average unemployment rate in year $t$ between the South and the North

$\mathrm{E}_{t}=\left(\mathrm{E}_{\mathrm{S}}-\mathrm{E}_{\mathrm{N}}\right)_{\mathrm{t}}$ or $\left(\frac{\mathrm{E}_{\mathrm{S}}}{\mathrm{E}_{\mathbf{N}}}\right)_{\mathrm{t}}=$ difference or ratio in the average nonagricultural employment growth in year $t$ between the South and the North

$\mathrm{W}_{\mathrm{t}}=\left(\mathrm{W}_{\mathrm{S}}-\mathrm{W}_{\mathrm{N}}\right)_{\mathrm{t}}$ or $\left(\frac{\mathrm{W}_{\mathrm{S}}}{\mathrm{W}_{\mathrm{N}}}\right)_{\mathrm{t}}=$ difference or ratio in the average real industrial wage in year $t$ between the South and the North

$Y_{t}=\left(Y_{S}-Y_{N}\right)_{t}$ or $\left(\frac{Y_{S}}{Y_{N}}\right)_{t}=\begin{aligned} & \text { difference or ratio in the average real } \\ & \text { income of employed workers in year } t\end{aligned}$ between the South and the North

The migration figures for 1961-2 are overreported because of a change in the migration laws in February 1961 making it easier for migrating workers to register. ${ }^{4}$ This is taken into consideration by using a dummy variable which takes the value of one for 1961-2 and zero for all other years.

Theory postulates that $\mathrm{M}_{\mathrm{SN} t}$ is directly related to $\mathrm{U}_{\mathrm{t}}$ and inversely related to $\mathrm{E}_{\mathrm{t}}$ and $\mathrm{W}_{\mathrm{t}}$ or $\mathrm{Y}_{\mathrm{t} .}{ }^{5}$ Theory also suggests that the difference rather than the ratio form of the independent variables is to be preferred (Becker [1, pp. 39-41] $)^{6}$. This has been used empirically by Laber and Chase [11] and Williamson [20]. On the other hand, the ratio form has been suggested by Hart [5] and used empirically by Lowry [12], Rogers [14] and Sahota [15] among others. Since in the final analysis this is an empirical question, we follow Walsh in this study by testing both forms.

The following four models will be tested econometrically:

Static Expectations:

(1) $\mathrm{MSNt}_{\mathrm{SN}}=\alpha_{0}+\alpha_{1} \mathrm{U}_{\mathrm{t}}+\alpha_{2} \mathrm{E}_{\mathrm{t}}+\alpha_{3} \mathrm{~W}_{\mathrm{t}}+\alpha_{{ }_{4} \mathrm{D}}+\mathbf{e}_{\mathrm{t}}$

Dynamic Expectations: ${ }^{7}$

(2) $\mathrm{MSN}_{\mathrm{SN}}=\beta_{0}+\beta_{1} \mathrm{U}_{\mathrm{t}}+\beta_{2} \mathrm{E}_{\mathrm{t}}+\beta_{3} \mathrm{~W}_{\mathrm{t}}+\beta_{4} \mathrm{M}_{\mathrm{SN} t-1}$

$+\beta_{5} \mathrm{D}+\mathrm{v}_{\mathrm{t}}$ 
Extrapolative Expectations:

(3) $\quad \mathrm{MsN}_{\mathrm{t}}=\delta_{0}+\delta_{1} \mathrm{U}_{\mathrm{t}}^{*}+\delta_{2} \mathrm{E}_{\mathrm{t}}^{*}+\delta_{3} \mathrm{~W}_{\mathrm{t}}^{*}+\delta_{4} \mathrm{D}+\mathrm{u}_{\mathrm{t}} \quad$ where

(4) $\quad \mathrm{U}_{\mathrm{t}}^{*}=\mathrm{U}_{\mathrm{t}}+\lambda\left(\mathrm{U}_{\mathrm{t}}-\mathrm{U}_{\mathrm{t}-1}\right)=\mathrm{U}_{\mathrm{t}}+\lambda \Delta \mathrm{U}_{\mathrm{t}}$

The same is true for $\mathrm{E}_{\mathrm{t}}^{*}$ and $\mathrm{W}_{\mathrm{t}}^{*}$, so that we get:

(5) $\quad \mathrm{M}_{\mathrm{SNt}}=\delta_{0}+\delta_{1} \mathrm{U}_{\mathrm{t}}+\delta_{1} \lambda \Delta \mathrm{U}_{\mathrm{t}}+\delta_{2} \mathrm{E}_{\mathrm{t}}+\delta_{2} \lambda \Delta \mathrm{E}_{\mathrm{t}}$

$+\delta_{3} \mathrm{~W}_{\mathrm{t}}+\delta_{3} \lambda \Delta \mathrm{W}_{\mathrm{t}}+\delta_{4} \mathrm{D}+\mathrm{u}_{\mathrm{t}}$

Information Flow:

(6) $\mathrm{MSN}_{\mathrm{t}}=\theta_{0}+\theta_{1} \mathrm{U}_{\mathrm{t}}+\theta_{2} \mathrm{E}_{\mathrm{t}}+\theta_{\mathrm{s}} \mathrm{W}_{\mathrm{t}}+\theta_{\mathrm{t}} \mathrm{MS}_{\mathrm{t}}$

$+\theta_{5} \mathrm{D}+\varepsilon_{\mathrm{t}} \quad$ where

$\mathrm{MS}_{\mathrm{t}}=$ stock of migrant workers from the South residing in the North in year $t$

Previous migrants send information back home on opportunities in the North and generally facilitate further migration from the South (Greenwood [3]). We do not have annual $\mathrm{MS}_{\mathrm{t}}$ data, but setting $\mathrm{MSN}_{\mathrm{t}-1}$ equal to $\mathrm{MS}_{\mathrm{t}}-\mathrm{MS}_{\mathrm{t}-1}{ }^{8}$, we can specify this information flow model as:

(7) $\mathrm{MSNt}_{\mathrm{SN}}=\theta_{1} \Delta \mathrm{U}_{\mathrm{t}}+\theta_{2} \Delta \mathrm{E}_{\mathrm{t}}+\theta_{3} \Delta \mathrm{W}_{\mathrm{t}}+\theta_{4} \mathrm{MSN}_{\mathrm{S}-1}$

$+\theta_{5} \mathrm{D}+\eta_{\mathrm{t}}$

Equation (7) will also be estimated with a constant term (which is equivalent to including a time trend in (7)).

The dynamic expectations and the information flow models face serial correlation if the static expectations model does not. The result is that the OLS estimates are biased and inconsistent, the standard errors are underestimated and the Durbin-Watson statistic is no longer appropriate as a measure of serial correlation.

\section{Empirical Results}

We analyzed the flow of labor migration from the South $(\mathrm{S})$ to the Northwest (NW), to the Northwest-Center (NWC) and to the North (N) as a whole from 1958 to 1974 (inclusive). Since theory does not specify the form of the relationship, we estimated the four models with OLS in linear and inverse semilog form. ${ }^{9}$ The latter gave better results and are reported in Tables 1 to 4 . 
TABLE 1: Static Expectations Model

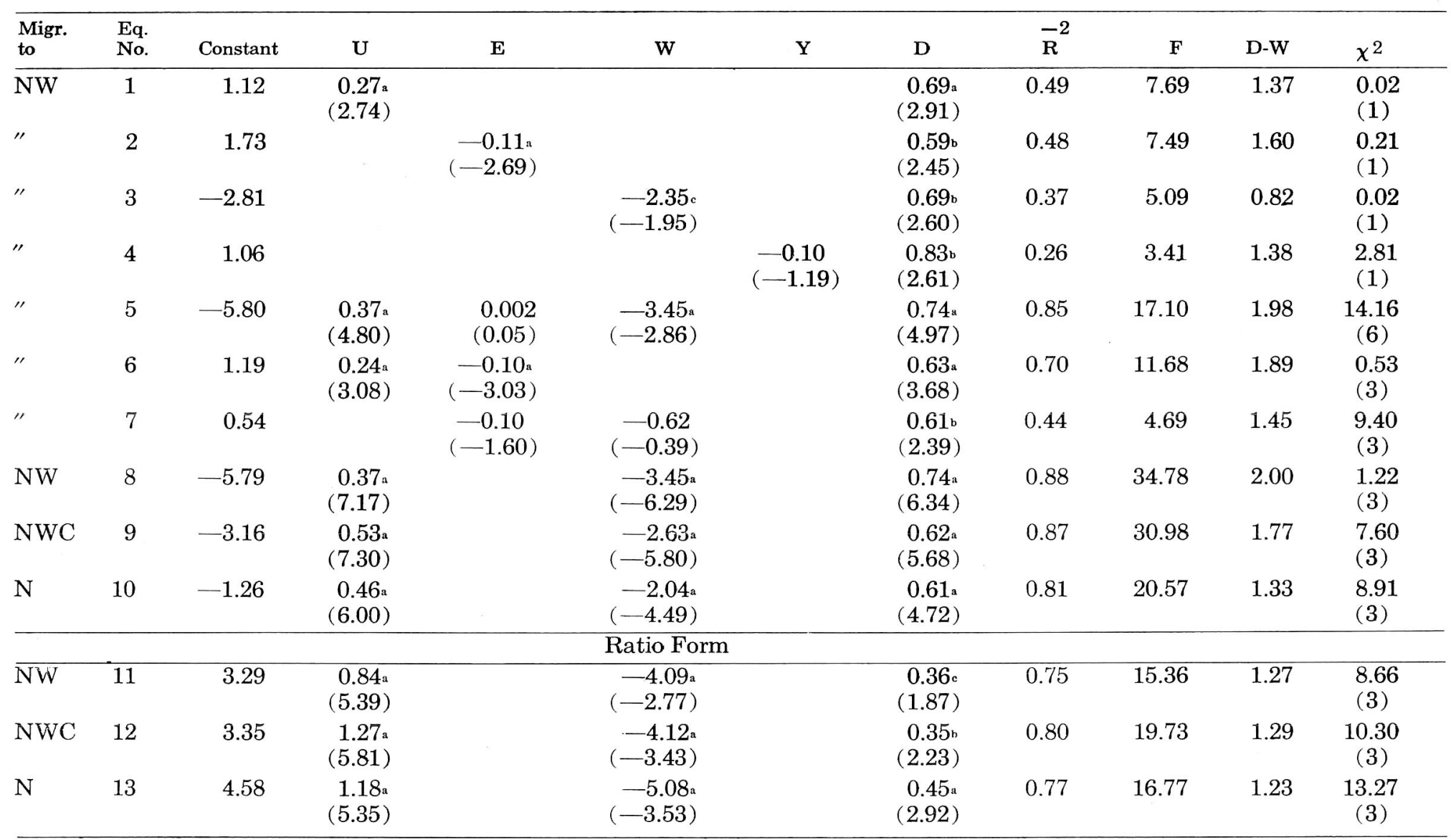

Figures in parenthesis are $t$-values (except for those below $\chi^{2}$ which refer to degrees of freedom) $\mathrm{a}$ - Significant at the 0.01 level
$\mathrm{b}$ - Significant at the 0.05 level

$\mathrm{b}$ - Significant at the 0.05 level
$\mathrm{c}$ - Significant at the 0.10 level 
TABLE 2: Dynamic Expectations Model

\begin{tabular}{|c|c|c|c|c|c|c|c|c|c|c|c|}
\hline $\begin{array}{l}\text { Migr } \\
\text { to }\end{array}$ & $\begin{array}{l}\text { Eq. } \\
\text { No. }\end{array}$ & Constant & $\mathbf{U}$ & $\mathbf{E}$ & $\mathbf{W}$ & $\mathbf{Y}$ & $\mathbf{M}_{t-1}$ & D & $\overline{\mathrm{R}}^{2}$ & $\mathbf{F}$ & $\chi^{2}$ \\
\hline NW & 1 & 0.58 & $\begin{array}{r}0.23 \mathrm{~b} \\
(2.59)\end{array}$ & & & & $\begin{array}{r}0.37 \mathrm{~b} \\
(2.21)\end{array}$ & $\begin{array}{c}0.57 \mathrm{~h} \\
(2.64)\end{array}$ & 0.61 & 8.40 & $\begin{array}{l}1.57 \\
(3)\end{array}$ \\
\hline " & 2 & 1.16 & & $\begin{array}{c}0.33^{\prime} \\
(-2.16)\end{array}$ & & & $\begin{array}{c}0.32 \mathrm{c} \\
(1.81)\end{array}$ & $\begin{array}{c}0.50 \mathrm{~b} \\
(2.19)\end{array}$ & 0.56 & 7.03 & $\begin{array}{l}2.59 \\
(3)\end{array}$ \\
\hline " & 3 & -1.43 & & & $\begin{array}{c}-1.32 \\
(-0.10)\end{array}$ & & $\begin{array}{c}0.34 \\
(1.51)\end{array}$ & $\begin{array}{c}0.56 \mathrm{c} \\
(2.13)\end{array}$ & 0.43 & 4.52 & $\begin{array}{r}4.77 \\
(3)\end{array}$ \\
\hline " & 4 & 0.64 & & & & $\begin{array}{c}-0.05 \\
(-0.68)\end{array}$ & $\begin{array}{c}0.42 \mathrm{c} \\
(2.00)\end{array}$ & $\begin{array}{r}0.61 \text { c } \\
(2.02)\end{array}$ & 0.40 & 4.16 & $\begin{array}{c}4.56 \\
(3)\end{array}$ \\
\hline " & 5 & -5.80 & $\begin{array}{r}0.37 \mathrm{a} \\
(4.80)\end{array}$ & $\begin{array}{r}0.002 \\
(0.05)\end{array}$ & $\begin{array}{r}-3.45 \text { a } \\
(-2.86)\end{array}$ & & $\begin{array}{c}0.01 \\
(0.08)\end{array}$ & $\begin{array}{c}0.73 \mathrm{a} \\
(4.97)\end{array}$ & 0.85 & 17.10 & $\begin{array}{r}21.42 \\
(10)\end{array}$ \\
\hline " & 6 & 0.81 & $\begin{array}{r}0.21 \mathrm{a} \\
(2.97)\end{array}$ & $\begin{array}{l}-0.08^{\mathrm{b}} \\
(-2.59)\end{array}$ & & & $\begin{array}{c}0.25 \\
(1.77)\end{array}$ & $\begin{array}{c}0.55 a \\
(3.15)\end{array}$ & 0.75 & 11.24 & $\begin{array}{l}3.30 \\
(6)\end{array}$ \\
\hline " & 7 & 0.77 & & $\begin{array}{c}-0.08 \\
(-1.40)\end{array}$ & $\begin{array}{c}-0.61 \\
(-0.38)\end{array}$ & & $\begin{array}{c}0.23 \\
(1.75)\end{array}$ & $\begin{array}{c}0.61 a \\
(3.81)\end{array}$ & 0.47 & 5.81 & $\begin{array}{c}13.16 \\
(6)\end{array}$ \\
\hline NW & 8 & -5.72 & $\begin{array}{r}0.37 \mathrm{a} \\
(6.09)\end{array}$ & & $\begin{array}{r}-3.41 \mathrm{a} \\
(-4.68)\end{array}$ & & $\begin{array}{c}0.01 \\
(0.10)\end{array}$ & $\begin{array}{c}0.73 a \\
(5.59)\end{array}$ & 0.87 & 23.74 & $\begin{array}{l}8.61 \\
(6)\end{array}$ \\
\hline NWC & 9 & -2.98 & $\begin{array}{r}0.48 \mathrm{a} \\
(7.34)\end{array}$ & & $\begin{array}{r}-2.31 \mathrm{a} \\
(-5.70)\end{array}$ & & $\begin{array}{r}0.20 \mathrm{~b} \\
(2.31)\end{array}$ & $\begin{array}{c}0.55^{\mathrm{a}} \\
(5.68)\end{array}$ & 0.90 & 33.74 & $\begin{array}{l}9.98 \\
(6)\end{array}$ \\
\hline $\mathrm{N}$ & 10 & -1.54 & $\begin{array}{r}0.41^{a} \\
(6.82)\end{array}$ & & $\begin{array}{r}-1.86 a \\
(-5.30)\end{array}$ & & $\begin{array}{r}0.28 \mathrm{a} \\
(3.01)\end{array}$ & $\begin{array}{c}0.51_{\text {: }} \\
(5.01)\end{array}$ & 0.89 & 29.00 & $\begin{array}{c}10.24 \\
(6)\end{array}$ \\
\hline \multicolumn{12}{|c|}{ Ratio Form } \\
\hline$\overline{N W}$ & 11 & 3.06 & $\begin{array}{r}0.75 a \\
(4.28)\end{array}$ & & $\begin{array}{r}-3.93 \mathrm{~b} \\
(-2.67)\end{array}$ & & $\begin{array}{c}0.16 \\
(1.08)\end{array}$ & $\begin{array}{c}0.32 \\
(1.65)\end{array}$ & 0.76 & 11.99 & $\begin{array}{c}13.66 \\
(6)\end{array}$ \\
\hline NWC & 12 & 3.01 & $\begin{array}{r}1.12 \mathrm{a} \\
(5.14)\end{array}$ & & $\begin{array}{r}-3.95 \mathrm{a} \\
(-3.52)\end{array}$ & & $\begin{array}{c}0.20 \\
(1.67)\end{array}$ & $\begin{array}{c}0.29 c \\
(1.96)\end{array}$ & 0.83 & 17.92 & $\begin{array}{c}13.22 \\
(6)\end{array}$ \\
\hline $\mathrm{N}$ & 13 & 4.08 & $\begin{array}{c}1.05 \mathrm{a} \\
(5.19)\end{array}$ & & $\begin{array}{r}-4.88 \mathrm{a} \\
(-3.89)\end{array}$ & & $\begin{array}{r}0.25 \mathrm{c} \\
(2.14)\end{array}$ & $\begin{array}{r}0.36 \mathrm{~b} \\
(2.59)\end{array}$ & 0.83 & 17.82 & $\begin{array}{c}15.14 \\
(6)\end{array}$ \\
\hline
\end{tabular}

Figures in parenthesis are t-values (except for those below $\chi^{2}$ which refer to degrees of freedom)

a - Significant at the 0.01 leve 
TABLE 3: Extrapolative Expectations Model

\begin{tabular}{|c|c|c|c|c|c|c|c|c|c|c|c|}
\hline $\begin{array}{l}\text { Migr. } \\
\text { to }\end{array}$ & $\begin{array}{l}\text { Eq. } \\
\text { No. }\end{array}$ & Constant & $\mathbf{U}$ & $\Delta U$ & W & $\Delta \mathrm{W}$ & D & $\begin{array}{l}-2 \\
\mathbf{R}\end{array}$ & $\mathbf{F}$ & D-W & $\chi^{2}$ \\
\hline$\overline{N W}$ & 1 & 1.08 & $\begin{array}{r}0.30 \mathrm{a} \\
(2.70)\end{array}$ & $\begin{array}{c}-0.10 \\
(-0.62)\end{array}$ & & & $\begin{array}{r}0.66 n \\
(2.68)\end{array}$ & 0.46 & 5.00 & 1.39 & $\begin{array}{l}2.82 \\
(3)\end{array}$ \\
\hline " & 2 & -2.18 & & & $\begin{array}{c}-2.02 \\
(-1.33)\end{array}$ & $\begin{array}{c}-0.46 \\
(-0.37)\end{array}$ & $\begin{array}{r}0.69_{\mathrm{b}} \\
(2.48)\end{array}$ & 0.32 & 3.19 & 0.93 & $\begin{array}{l}5.63 \\
(3)\end{array}$ \\
\hline NW & 3 & -7.29 & $\begin{array}{r}0.38 \mathrm{a} \\
(6.92)\end{array}$ & $\begin{array}{c}0.06 \\
(0.61)\end{array}$ & $\begin{array}{r}-4.21_{\mathrm{a}} \\
(-5.50)\end{array}$ & $\begin{array}{c}0.85 \\
(1.44)\end{array}$ & $\begin{array}{r}0.77 \mathrm{a} \\
(6.40)\end{array}$ & 0.88 & 21.41 & 1.78 & $\begin{array}{r}13.07 \\
(10)\end{array}$ \\
\hline NWC & 4 & -4.15 & $\begin{array}{r}0.62 \mathrm{a} \\
(8.98)\end{array}$ & $\begin{array}{c}-0.18 \mathrm{~b} \\
(-2.34)\end{array}$ & $\begin{array}{l}-3.15 a \\
(-6.37)\end{array}$ & $\begin{array}{c}0.56 \\
(1.14)\end{array}$ & $\begin{array}{r}0.57 \mathrm{a} \\
(6.13)\end{array}$ & 0.91 & 28.42 & 2.11 & $\begin{array}{c}17.43 \\
(10)\end{array}$ \\
\hline$N$ & 5 & -1.81 & $\begin{array}{r}0.54 a \\
(6.30)\end{array}$ & $\begin{array}{c}-0.19 \\
(-1.71)\end{array}$ & $\begin{array}{r}-2.39 \mathrm{a} \\
(-4.46)\end{array}$ & $\begin{array}{c}0.25 \\
(0.38)\end{array}$ & $\begin{array}{r}0.57 \mathrm{a} \\
(4.50)\end{array}$ & 0.83 & 14.22 & 1.47 & $\begin{array}{c}17.70 \\
(10)\end{array}$ \\
\hline \multicolumn{12}{|c|}{ Ratio Form } \\
\hline NW & 6 & 3.38 & $\begin{array}{r}0.87_{\mathrm{a}} \\
(4.35)\end{array}$ & $\begin{array}{c}-0.07 \\
(-0.25)\end{array}$ & $\begin{array}{r}-4.26 \mathrm{~b} \\
(-2.39)\end{array}$ & $\begin{array}{c}-0.21 \\
(-0.03)\end{array}$ & $\begin{array}{c}0.35 \\
(1.57)\end{array}$ & 0.70 & 7.62 & 1.26 & $\begin{array}{c}19.32 \\
(10)\end{array}$ \\
\hline NWC & 7 & 3.51 & $\begin{array}{r}1.43 \mathrm{a} \\
(5.06)\end{array}$ & $\begin{array}{c}-0.29 \\
(-0.98)\end{array}$ & $\begin{array}{l}-4.60: \mathrm{a} \\
(-3.21)\end{array}$ & $\begin{array}{c}-2.75 \\
(-0.52)\end{array}$ & $\begin{array}{r}0.33 \text { c } \\
(1.89)\end{array}$ & 0.78 & 10.98 & 1.20 & $\begin{array}{c}19.80 \\
(10)\end{array}$ \\
\hline $\mathrm{N}$ & 8 & 4.77 & $\begin{array}{r}1.26 \mathrm{a} \\
(4.30)\end{array}$ & $\begin{array}{c}-0.17 \\
(-0.47)\end{array}$ & $\begin{array}{r}-5.43 \mathrm{a} \\
(-3.10)\end{array}$ & $\begin{array}{c}-0.37 \\
(-0.07)\end{array}$ & $\begin{array}{r}0.44 \mathrm{~b} \\
(2.44)\end{array}$ & 0.73 & 8.48 & 1.19 & $\begin{array}{c}21.61 \\
(10)\end{array}$ \\
\hline
\end{tabular}

Figures in parenthesis are $t$-values (except for those below $\chi^{2}$ which refer to degrees of freedom)

a - Significant at the 0.01 level

$\mathrm{b}$ - Significant at the 0.05 level

$c$ - Significant at the 0.10 level 


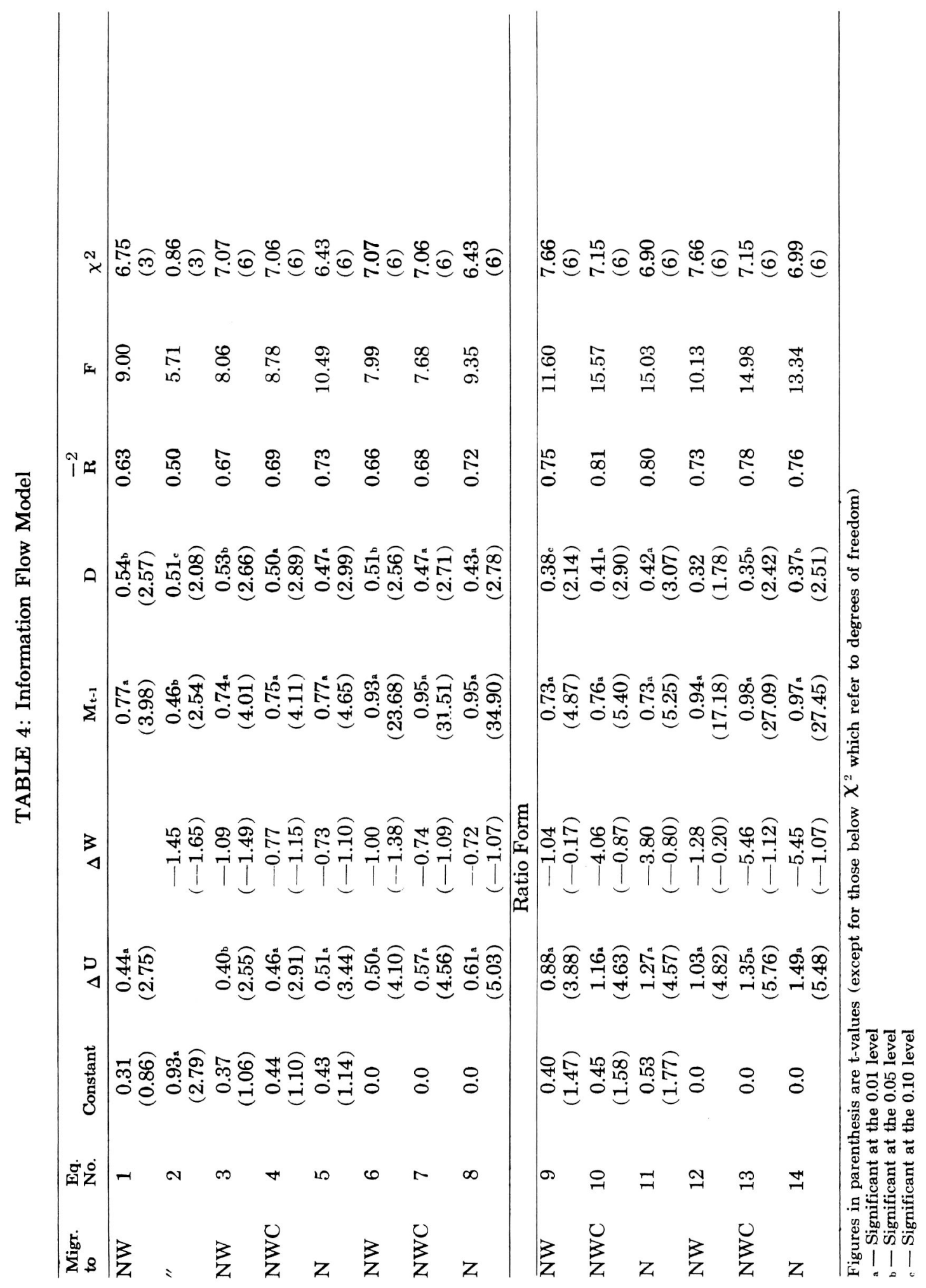


Looking at the static results in Table 1, we see that variables $\mathrm{U}, \mathrm{E}$ and $\mathrm{D}$ in equations 1 and 2 are statistically significant at better than the 0.01 level. From equations 3 and 4, we see that W performs better than Y. This is true for all other equations in Table 1 and so the $\mathrm{W}$ results only are reported subsequently. Equation 5 including variables U, E, W, and $\mathrm{D}$ has a relatively high $\overline{\mathrm{R}}^{2}$ (corrected for degrees of freedom) but $\mathrm{E}$ is not statistically significant, the D-W indicates the presence of serial correlation and the $\chi^{2}$ test shows serious multicollinearity. ${ }^{10}$ Equations 5, 6,7 and 8 indicate that $\mathrm{E}$ is statistically highly insignificant whenever $\mathrm{W}$ is included in the regression (due to the high intercorrelation between them) and justifies dropping the former. Thus, we end up with equation 8 for migration from the South to the Northwest. In equation 8 , all the variables have the correct sign, we have the high $\overline{\mathrm{R}}^{2}$ of 0.88 and there is neither evidence of serial correlation nor of serious multicollinearity. The same process repeated for labor migration from $\mathrm{S}$ to NWC and $\mathrm{N}$ gives identical conclusions and so only final equation 9 and 10 are reported. Equation 8 shows a slightly better fit than 9 and much better than 10 (which also faces autocorrelation and serious multicollinearity). This is an interesting result in that it shows that as we include less industrial and developed areas of the North, non-economic factors increase in relative importance as determinants of labor migration from the South. Finally, equations 11, 12 and 13 which utilize the ratio form of the variables show much lower $\overline{\mathrm{R}}^{2}$, indicate the presence of serial correlation and serious multicollinearity. This confirms the theoretical point made earlier and is the opposite of the conclusions reached by Walsh (who, however, found only very marginally better results with the ratio than with the difference form of the variables).

Equation 8 in Table 1 shows that an increase of one percentage point in the (positive) difference in the unemployment rate between the $\mathbf{S}$ and the NW, increases the net migration of workers from the $\mathrm{S}$ to the NW by $\ln 0.37$ or by 1.45 per thousand workers in the South. On the other hand, a 100,000 Lire increase in the (negative) difference in the average annual real industrial wages between the $\mathrm{S}$ and the NW, increases the net migration of workers from the $\mathrm{S}$ to the NW by $\ln 3.45$ or by 31.50 per thousand workers in the South. The significance of the magnitude of the coefficients in the other equations can be similarly interpreted.

Turning to the dynamic results in Table 2, we see from equations 3 and 4 that $\mathrm{W}$ performs better than $\mathrm{Y}$ and from equations $5,6,7$ and 8 that $\mathrm{E}$ can be dropped. Thus, we end up with equations 8, 9, 10. From these we get the additional very interesting result that as we include less developed areas of the North, the importance of previous migration as a determinant of migration in each year becomes more and more important and provide a missing component in equations 9 and 10 of Table 1 . $^{11}$ Again (as in Table 1), equations 11, 12 and 13 which use the variables in ratio form have much lower $\overline{\mathrm{R}}^{2}$ and all face serious multicollinearity (while equations 8,9 and 10 do not). 
The extrapolative expectations mode ${ }^{12}$ results in Table 3 show slightly higher $\overline{\mathrm{R}}^{2}$ for migration to the NWC and $\mathrm{N}$ than the static model of Table 1, but there evidence of serial correlation, not present in the static results. The results of equations 6,7 and 8 (with the variables in ratio form) are again clearly inferior on every account to equations 3,4 and 5 (with the variables in difference form).

In all fourteen equations of the information flow model results in Table 4 , all variables exhibit the right sign and are generally statistically highly significant except for the $\Delta \mathrm{W}$ variable. The results are slightly better when the constant is included and with the variables in the ratio form but are all inferior to the results of the static model in Table 1 (which also do not face the estimation problems of Table 4).

\section{Summary and Conclusions}

Emigration of workers from the South to the North of Italy can be regarded primarily as a response to better economic opportunities in the North. This conclusion can be accepted with confidence in view of the superior data utilized and better results obtained than in most other studies on internal migration. Thus, the conclusion of Walsh and others as to the most important determinants of internal migration are strongly supported by this study.

Of the four models tested, the static expectations model gave the best results for emigration to the Northwest, while the dynamic expectations model improved the fit for migration to the Northwest-Center and for the North as a whole. The extrapolative expectations model gives equally good results except for the presence of serial correlation and the statistically insignificant results for the change in the unemployment and wage difference variables. The information flow model did not perform as well as the other three models.

The generally good performance of the static expectations model is reasonable in view of the fact that South-North labor migration in Italy is characterized by very low mobility costs and can be easily reversed. This, too, supports the results of Walsh for Irish migration to Britain. Presumably, in cases where mobility costs are high and the migration decision not easily reversed, the static expectations model may not perform as well. However, this is primarily an empirical question. Equations 8 and 10 of Tables 1 and 2 are explored further and extended to migration from each of the seven regions of the South in a forthcoming study.

The models with the variables expressed in difference form generally performed better than the variables in ratio form. Walsh, however, found slightly better results for the variables in ratio form. At this point, there seems to be as many empirical studies using the ratio as the difference form of the explanatory variables and from an empirical point of view, no conclusions can be reached as to which is better. Thus, in future empirical work, it may be necessary to test both forms even though the re- 
sults, as shown by Walsh and by this study, may not differ much. In the present study, real industrial wages consistently performed better than the real income variable, and employment growth was statistically highly insignificant in all models because of its high intercorrelation with the earnings variable.

The present study implicitly assumed a one-way causation between the dependent variable and the explanatory variables. To the extent that they are jointly determined, the above results face simultaneous equation bias. A complete simultaneous equation model of interregional and international migration in Italy is now in preparation.

\section{FOOTNOTES}

1.For an extensive bibliography, see Greenwood [4] and Shaw [16].

2 Walsh used only unemployment rates but Johnston (commenting on a paper by Oliver [13, p. 71]) and Hart [5, pp. 134-135] pointed out that it cannot be inferred that regions with low unemployment rates are also regions of rapidly growing employment opportunities.

3Walsh used only the former, while most other migration studies used the latter.

4 The amount of overreporting for these years is probably in the order of $20 \%$. A more precise estimate is not available and cannot be made.

5Data on $U_{t}$ and $E_{t}$ are published by ISTAT [9], for $W_{t}$ by INAIL [7] and for $Y_{t}$ by Tagliacarne [17] and [18].

6 According to human capital theory, migration can be viewed as an investment in human capital, and as such it responds to absolute real wage differences rather than ratios, since the present value of the investment will vary directly with the absolute differential (Laber and Chase [11, p. 797]). The difference form of the independent variables leads to the disadvantage that the absolute change in $U_{t}, E_{t}$, $\mathrm{W}_{t}$ or $\mathrm{Y}_{t}$ has the same impact on $\mathrm{M}$ re$\mathrm{SN}_{t}$

gardless of their level. This disadvantage, however, is often slight in the real world (Oliver [13, pp. 72 and 75]).

This is a general distributed lag model and not an adaptive expectations model, and so is essentially Walsh's [19, pp. 113 and 116] estimated equations (23) and (45).

8This is approximately true since the flow of migration from the South to the North and the return flow from the North to the South is composed almost entirely of workers born in the South.

${ }^{9}$ The semilog and double-log form could not be tested because some of the independent variables exhibited positive values in some years and negative in others.

10This is the Farrar Glauber [2] test for multicollinearity which is better known than the test proposed by Haitovsky [6] and used by Walsh. However, the two tests give identical conclusions for equations 1 and 10 . (The number in parenthesis below each $\chi^{2}$ value refers to degrees of freedom.)

${ }^{11}$ However, equations 9 and 10 in Table 2 face serious estimation problems not faced in Table 1.

12Results for the extrapolative expectations and information flow models also indicate that $\mathrm{W}$ performs better than $\mathrm{Y}$ and that variable E can safely be dropped. These results are not reported to save space but are available from the author on request. In addition, for the extrapolative expectations model, the inclusion of $\mathrm{E}$ and $\Delta \mathrm{E}$ also leads to too few degrees of freedom.

\section{REFERENCES}

1. Becker, G., "Investment in Human Capital: A Theoretical Analysis," Journal of Political Economy, Supplement, Oct. 1962, 9-49.

2. Farrar, D. E., and Glauber, R. R., "Multicollinearity in Regression Analysis," $R e$ view of Economics and Statistics, Feb. 1967, 92-107.

3. Greenwood, M. J., "An Analysis of the Determinants of Geographic Labor Mobility in the United States," Review of Economics and Statistics, May 1969, 189194.

4. Greenwood, M. J., "Research on Internal Migration in the United States: A Survey,"
Journal of Economic Literature, June 1975, 397-433.

5. Hart, R. A., "Interregional Economic Migration: Some Theoretical Considerations (Part I)," Journal of Regional Science, August 1975, 127-138.

6. Haitovsky, Y., "Multicollinearity in $\mathrm{Re}-$ gression Analysis: Comment," Review of Economics and Statistics, Nov. 1969, 486489

7. INAIL, Notiziario Statistico. Rome: INAIL, Annual (1958-1974).

8. ISTAT, Annuario di Statistiche Demografiche. Rome: ISTAT, Annual (19581975). 
9. ISTAT, Annuario di Statistiche del Lavoro Rome: ISTAT, Annual (1959-1975, with 1958-1974 data).

10. ISTAT, Popolazione e Movimento Anagrafico dei Comuni. Rome: ISTAT, Annual (1958-1974).

11. Laber, G., and Chase, R. X., "Interprovincial Migration in Canada as a Human Capital Decision," Journal of Political Economy, July/August 1971, 795-804.

12. Lowry, I., Migration and Metropolitan Growth: Two Analytical Models. San Francisco, Chandler, 1966.

13. Oliver, F. R., "Inter-regional Migration and Unemployment, 1951-1961," Journal of the Royal Statistical Society, 1964, 4275 .

14. Rogers, A., Matrix Analysis and Interregional Population Growth and Distribution. Berkely, University of California Press, 1968.

15. Sahota, G. S., "An Economic Analysis of Internal Migration in Brazil," Journal of
Political Economy, March/April 1968, 218245.

16. Shaw, R. P., Migration Theory and Fact Philadelphia: Regional Science Research Institute, 1975.

17. Tagliacarne, G., "Calcolo del Reddito nelle Regioni D'Italia," Moneta e Credito, 1960 and 1963 (with 1958 to 1962 data).

18. Tagliacarne, G., Il Reddito Prodotto nelle Regioni Italiane. Milano, Franco Angeli, 1972, 1973 and 1975 (with 1963 to 1974 data).

19. Walsh, B. M., "Expectations, Information, and Human Migration: Specifying an Econometric Model of Irish Migration to Britain," Journal of Regional Science, April 1974, 107-120.

20. Wilkinson, M., "European Migration to the United States: An Econometric Analysis of Aggregate Labor Supply and Demand," Review of Economics and Statistics, Aug. 1970, 272-279. 